\title{
ORAL PENICILLIN IN THE TREATMENT OF GONOCOCCAL URETHRITIS
}

\author{
BY \\ G. O. HORNE \\ From the Department of Venereal Diseases, \\ Royal Infirmary, Edinburgh
}

Probably the most common treatment at the present time of uncomplicated acute gonococcal urethritis in the male is a single intramuscular injection of 300,000 units of penicillin suspended in oil-wax, or of procaine penicillin suspended in oil. The failure rate with each of these preparations is low, and unpleasant side effects, especially with procaine penicillin, seldom occur. The most recent preparations of procaine penicillin are easy to handle, and no great technical or therapeutic advance in this method of treatment is to be expected.

Penicillin has frequently been shown to be effective in various infections when administered by mouth, although the required dose is from three to six times that by injection. The scarcity of reports on the use of oral penicillin for the treatment of gonorrhœa does not indicate an ignorance on the part of venereologists of the potentialities of oral penicillin, but rather their awareness of the dangers associated with oral treatment of any venereal disease, and their fear that the larger dose of penicillin required will increase the danger, which accompanies any penicillin treatment of gonorrhœa, of " masking" incubating syphilis.

Nevertheless oral preparations of penicillin are available, and it is important to determine whether they can provide a successful treatment for gonorrhœa, and if so, what the minimum effective dose is. The investigation reported here showed that penicillin given orally was in fact as successful as by any other route, but the minimum effective dose has not yet been established. The dose used was chosen to give blood levels similar to those reached after standard doses of penicillin by injection.

\section{Methods}

Estimation of the Blood Penicillin.-Blood penicillin estimations were made by the method of Mackie and McCartney (1948), and were in every case carried out by Dr. W. M. Wilson.
Assessment of Failure Rate.-Cases of gonococcal urethritis failing to respond to chemotherapy may be divided into those in which there is no clinical improvement and gonococci persist in the urethral discharge, and those in which the discharge returns after a period of freedom and gonococci are again present. In none of the series discussed in this paper did any example of the former type occur.

When gonococci re-appear after an interval of freedom there has been either a relapse (treatment failure) or a re-infection, and it is sometimes difficult to determine to which category a case belongs. Cases in which a gonococcal urethritis recurred within seven days of an admitted re-exposure to the risk of contracting venereal disease were not considered failures. Cases in which the evidence was strongly in favour of re-infection in spite of denial were classified as " possible" failures, and cases in which there was no good evidence of re-infection were classified as "real" failures. The maximum failure rate was calculated from the sum of the last two groups, and is probably greater than the true failure rate as it includes some cases that were possibly re-infections. The minimum failure rate was calculated from the number of real failures, assuming that all the possible failures were in fact re-infections. This figure is probably less than the true failure rate as some of those classed as re-infections may have been relapses. Thus the true failure rate is likely to lie between the maximum and minimum rates as calculated. The day of relapse in each case is given in Table I, so that, if desired, it is possible to calculate the failure rate on the assumption that recurrence after any arbitrarily chosen number of days must be a re-infection.

In calculating the failure rate all cases observed for less than seven days after treatment were discarded. This is likely to have inflated the calculated failure rate as any cases relapsing during this period would probably have returned to the clinic. In 
TABLE I

FAILURE RATE AFTER TREATMENT OF GONORRHEA WITH DIFFERENT PREPARATIONS AND DOSES OF PENICILLIN (For criteria of cure and calculation of failure rate, see text)

\begin{tabular}{|c|c|c|c|c|c|c|}
\hline \multicolumn{2}{|c|}{ Preparation } & $\begin{array}{l}\begin{array}{c}\text { Penicillin } \\
\text { oil-wax } \\
\text { (early } \\
\text { preparation) }\end{array} \\
\text { (A) }\end{array}$ & $\begin{array}{c}\text { Penicillin } \\
\text { oil-wax } \\
\text { (3 recent } \\
\text { preparations) } \\
\text { (B) }\end{array}$ & $\begin{array}{c}\text { Procaine } \\
\text { penicillin } \\
\text { in oil } \\
\text { (4 recent } \\
\text { preparations) } \\
\text { (C) }\end{array}$ & $\begin{array}{c}\text { Procaine } \\
\text { penicillin } \\
\text { in oil } \\
\text { (2 recent } \\
\text { preparations) } \\
\text { (D) }\end{array}$ & $\begin{array}{c}\text { Oral penicillin } \\
\text { (calcium salt } \\
\text { with sodium } \\
\text { citrate) } \\
\text { (E) }\end{array}$ \\
\hline \multicolumn{2}{|l|}{ Dosage } & $300,000 \mathrm{U}$. & $300,000 \mathrm{U}$. & $300,000 \mathrm{U}$. & $150,000 \mathrm{U}$. & 1 mega $U$. \\
\hline \multicolumn{2}{|c|}{ Cases originally treated .. } & 24 & 299 & 153 & 50 & 50 \\
\hline \multirow{2}{*}{$\begin{array}{l}\text { Cases } \\
\text { omitted } \\
\text { in } \\
\text { calculating } \\
\text { failure } \\
\text { rate }\end{array}$} & $\begin{array}{l}\text { Received } \\
\text { adjuvant } \\
\text { treatment }\end{array}$ & 1 & 18 & 13 & 3 & 1 \\
\hline & $\begin{array}{l}\text { Period of } \\
\text { observation } \\
\text { less than } 7 \\
\text { days }\end{array}$ & 2 & 71 & 29 & 8 & 4 \\
\hline \multirow{5}{*}{$\begin{array}{l}\text { Successful } \\
\text { cases. } \\
\text { Period } \\
\text { of } \\
\text { observation } \\
\text { (weeks) }\end{array}$} & $1-4$ & 1 & 47 & 29 & 9 & 11 \\
\hline & $5-8$ & 3 & 29 & 8 & 2 & 2 \\
\hline & $9-12$ & 0 & 20 & 8 & 3 & 3 \\
\hline & $13-20$ & $?$ & 61 & 44 & 15 & 11 \\
\hline & $21+$ & 9 & 41 & 18 & 8 & 15 \\
\hline \multicolumn{2}{|c|}{ Total successful cases } & 15 & 198 & 107 & 37 & 42 \\
\hline \multirow{2}{*}{$\begin{array}{c}\text { Failures } \\
\text { (day of } \\
\text { relapse after } \\
\text { beginning } \\
\text { of } \\
\text { treatment) }\end{array}$} & $*$ Real & $3,3,3,4,5,7$ & $\begin{array}{c}4,7,8,11,17 \\
18,24,32\end{array}$ & 3,4 & 3 & 4,6 \\
\hline & *Possible & - & $2+, 19,35,77$ & 9,16 & $2 t$ & 26 \\
\hline \multirow{2}{*}{$\begin{array}{l}\text { Failure } \\
\text { rate } \\
\text { per cent. }\end{array}$} & Max. & $28 \cdot 6$ & 3.9 & $1 \cdot 8$ & $2 \cdot 6$ & $4 \cdot 4$ \\
\hline & Min. & 28.6 & $5 \cdot 7$ & 3.6 & $5 \cdot 1$ & $6 \cdot 7$ \\
\hline
\end{tabular}

$\uparrow$ In these two cases a second injection of penícillin was given after 24 hours when a purulent urethral discharge persisted, although no gonococc were found in smears. The second injection was probably given unnecessarily.

addition, those cases which at any time during observation received adjuvant treatment (either with sulphonamides or by urethral irrigations) for persisting urethritis (but not associated with gonococci) are recorded separately and omitted from the total number cured. This will also tend to have augmented the calculated failure rate. These criteria were applied to all the series analysed in this paper.

\section{Results}

The Blood Penicillin Level Necessary for the Effective Treatment of Gonorrhoa.-A clinical trial of one of the earlier preparations of crystalline penicillin suspended in oil-wax (in which the proportion of wax was relatively small) gave some information about the relation between the blood penicillin level and the cure of gonorrhœa. In a series (A) of 24 unselected cases of uncomplicated acute gonococcal urethritis treated with 300,000 units of this preparation given by intramuscular injection there were six failures (Table I). Blood penicillin estimations on three normal subjects without gonorrhœa after the same dose of the same preparation showed that a bacteriostatic level $(0.03$ units penicillin per cc. of serum, or more) was maintained for less than six hours in two instances, and for less than nine hours in the third (Table II). 
TABLE II

PENICILLIN BLOOD LEVELS AFTER PARENTERAL ADMINISTRATION (UNITS OF PENICILLIN PER CC. OF SERUM)

\begin{tabular}{|c|c|c|c|c|c|c|c|c|c|c|c|}
\hline \multicolumn{2}{|l|}{ Penicillin } & \multirow{2}{*}{ Case } & \multicolumn{9}{|c|}{ Hours after administration of penicillin } \\
\hline Preparation & Dosage & & 1 & 2 & 3 & 4 & 6 & 7 & 8 & 9 & 12 \\
\hline \multirow[t]{3}{*}{$\begin{array}{l}\text { Series } A \\
\quad \text { Penicillin oil wax (early } \\
\text { preparation) }\end{array}$} & \multirow[t]{3}{*}{$300,000 \mathrm{U}$} & 1 & $2 \cdot 0$ & $0 \cdot 25$ & $0 \cdot 125$ & - & - & 0.03 & - & $\dagger$ & 一 \\
\hline & & 2 & $1 \cdot 0$ & $0 \cdot 5$ & $0 \cdot 125$ & - & $\dagger$ & - & - & $\dagger$ & 一 \\
\hline & & 3 & $1 \cdot 0$ & 0.5 & $0 \cdot 125$ & - & $\dagger$ & - & - & $\dagger$ & - \\
\hline \multirow[t]{7}{*}{$\begin{array}{l}\text { Series } D \\
\quad \text { Procaine penicillin in oil }\end{array}$} & \multirow[t]{7}{*}{$150,000 \mathrm{U}$} & 1 & $1 \cdot 0$ & $2 \cdot 0$ & 0.75 & - & 0.03 & - & $\dagger$ & 一 & $\dagger$ \\
\hline & & $2^{*}$ & - & $1 \cdot 0$ & - & $0 \cdot 5$ & - & - & $0 \cdot 25$ & - & - \\
\hline & & $3 *$ & 一 & $1 \cdot 0$ & - & $0 \cdot 25$ & - & 一 & - & - & 0.015 \\
\hline & & $4^{*}$ & $0 \cdot 25$ & 0.5 & - & $0 \cdot 25$ & - & - & - & - & $\dagger$ \\
\hline & & $5^{*}$ & 0.5 & 0.5 & - & $0 \cdot 25$ & - & - & - & - & 0.015 \\
\hline & & 6 & - & 0.25 & - & $0 \cdot 5$ & $0 \cdot 125$ & - & 0.03 & - & $\dagger$ \\
\hline & & 7 & - & - & - & - & 0.06 & - & - & - & $\dagger$ \\
\hline
\end{tabular}

* Normal subjects.

† Penicillin not detected by method used.

A series (D) of fifty similar cases of gonorrhœa was treated with 150,000 units of reliable modern preparations of procaine penicillin suspended in oil. The only selection of cases for this series was the omission of those in which it was unlikely that follow-up would be adequate. The failure rate was the same as in an unselected series in which a dose of 300,000 units of similar preparations of procaine penicillin was used (Table I). Estimations of the blood penicillin level in three cases of series $D$ and in four other normal subjects given the same dose showed that after 150,000 units of procaine penicillin a bacteriostatic level sometimes persisted for eight hours but never for as long as twelve hours (Table II).

Trial Series with Oral Penicillin.-A trial of oral penicillin was made in 50 cases (series E) of uncomplicated acute gonococcal urethritis in the male. The diagnosis was made by staining smears of the urethral discharge. In 26 cases culture methods were also used, and gonococci were grown in 22 of these. The cases were spread over nine months (October 1948 to July 1949) in order that it should not become generally known in the clinic that gonorrhœa was being treated with tablets of penicillin. Selection of cases was influenced by the likelihood of adequate follow-up, and all of them were treated as out-patients. Nineteen of the cases were chosen because it was possible for them to be detained for repeated examination of the blood penicillin level, and in the first eighteen cases the second as well as the first dose of penicillin was taken under supervision. When it was realized that oral penicillin was apparently successful subsequent patients were allowed to take the second dose away from the clinic, the time being checked at their next visit.

The tablets, each containing 100,000 units of calcium penicillin buffered with sodium citrate, were broken up in the mouth and swallowed with a drink of water, the first dose being taken immediately the diagnosis was established. Two doses only were taken, each of five tablets (total dose, one mega unit). In twelve cases the second dose was taken three hours after the first one ; in 24 cases, four hours after; in nine cases, five hours after; and in five cases, six hours after. Blood penicillin levels were not obtained in any of the last fourteen cases. Patients were advised not to take a meal for at least an hour before the second dose was due.

The cases were carefully supervised and attended as out-patients more frequently than was the normal custom. The immediate clinical response was similar to that expected from parenteral penicillinrapid relief of symptoms and disappearance of the urethral discharge. Tests of cure, including culture of the prostatic secretion, were carried out in most cases between the third and fourth week after treatment, and again about two to three months later. Thirty-six cases have so far had a bacterio- 
TABLE III

PENICILLIN BLOOD LEVELS AFTER ORAL ADMINISTRATION OF TWO DOSES, EACH OF 0.5 MEGA UNIT, THE SECOND DOSE BEING GIVEN AT THE END OF THE FOURTH HOUR

(Units of penicillin per cc. of serum)

\begin{tabular}{|c|c|c|c|c|c|c|c|}
\hline \multirow{2}{*}{ Case } & \multicolumn{7}{|c|}{ Hours after administration of penicillin } \\
\hline & 1 & 2 & 4 & 5 & 6 & 8 & 9 \\
\hline 1 & $3 \cdot 0$ & $2 \cdot 0$ & $0 \cdot 38$ & 0.5 & - & $0 \cdot 25$ & - \\
\hline 2 & $2 \cdot 0$ & $2 \cdot 0$ & $0 \cdot 125$ & $2 \cdot 0$ & $1 \cdot 0$ & 一 & $0 \cdot 6$ \\
\hline 3 & $2 \cdot 0$ & - & 0.06 & $1 \cdot 0$ & - & $0 \cdot 06$ & - \\
\hline 4 & $1 \cdot 0$ & - & $0 \cdot 25$ & $0 \cdot 5$ & - & $0 \cdot 125$ & - \\
\hline 5 & $1 \cdot 0$ & - & 0.06 & $0 \cdot 25$ & - & 0.03 & - \\
\hline 6 & 0.5 & - & 0.06 & $0 \cdot 25$ & - & 0.06 & - \\
\hline 7 & 0.5 & - & 0.06 & 0.5 & - & 0.03 & - \\
\hline 8 & 0.5 & - & 0.03 & - & - & - & - \\
\hline 9 & $0 \cdot 25$ & - & - & 0.5 & - & 0.03 & - \\
\hline$* 10$ & - & - & 0.03 & - & - & - & 0.03 \\
\hline
\end{tabular}

logical test of cure on one occasion, and fourteen cases on two occasions.

The total period of observation of the cases is shown in Table I. The relatively short period in many of them was not always due to default. Other reasons included the transfer of cases elsewhere, treatment of concomitant syphilis with penicillin, and re-infection. Some cases were still under observation at the time of this analysis. In only one case was adjuvant treatment required for a persisting non-gonococcal urethritis.

Blood penicillin levels. - The levels one hour after the ingestion of the tablets showed the expected considerable variation (Table III). In ten cases in which an estimation was made four hours after the ingestion of 0.5 mega units a bacteriostatic level $(0.03$ units penicillin per cc. of serum) was present (Table III). In twelve cases a bacteriostatic level was present eight hours after the initial dose, whether the second dose had been taken three hours (three cases), or four hours (nine cases), after the first.

Failures.-Two cases relapsed early, one after four days and one after six days, and both were considered to be real failures. In the first, the second dose was taken under supervision four hours after the initial dose, and a bacteriostatic level of penicillin was maintained in the blood for at least nine hours (Case 10, Table III). In the other failure the second dose was not supervised, but was believed to have been taken three hours after the first dose, and no blood penicillin estimations were made. Both cases were subsequently cured with 300,000 units procaine penicillin.

In the third case that relapsed the second dose of penicillin was not supervised, but was stated to have been taken five hours after the initial one. The immediate response was good, but a purulent urethral discharge recurred on the 26th day after treatment, and was found to contain gonococci. The patient denied any risk of re-infection and according to the criteria adopted this must be categorized as a possible failure, but it was strongly suspected that the patient was in fact re-infected. $\mathrm{He}$ was an unreliable witness; no gonococcal infection could be found in the person he named as his regular consort ; the discharge re-appeared three days after an evening's drinking in company, although no further exposure was admitted; and he defaulted immediately after the urethral discharge had cleared up a second time following a course of sulphadiazine (penicillin was not repeated as he had developed urticaria after the oral tablets).

Reactions.-One patient, who had had parenteral penicillin a year previously, developed urticaria twelve days after treatment (see previous paragraph). One patient had a severe febrile reaction a few hours after the first dose ; the blood Wassermann reaction 


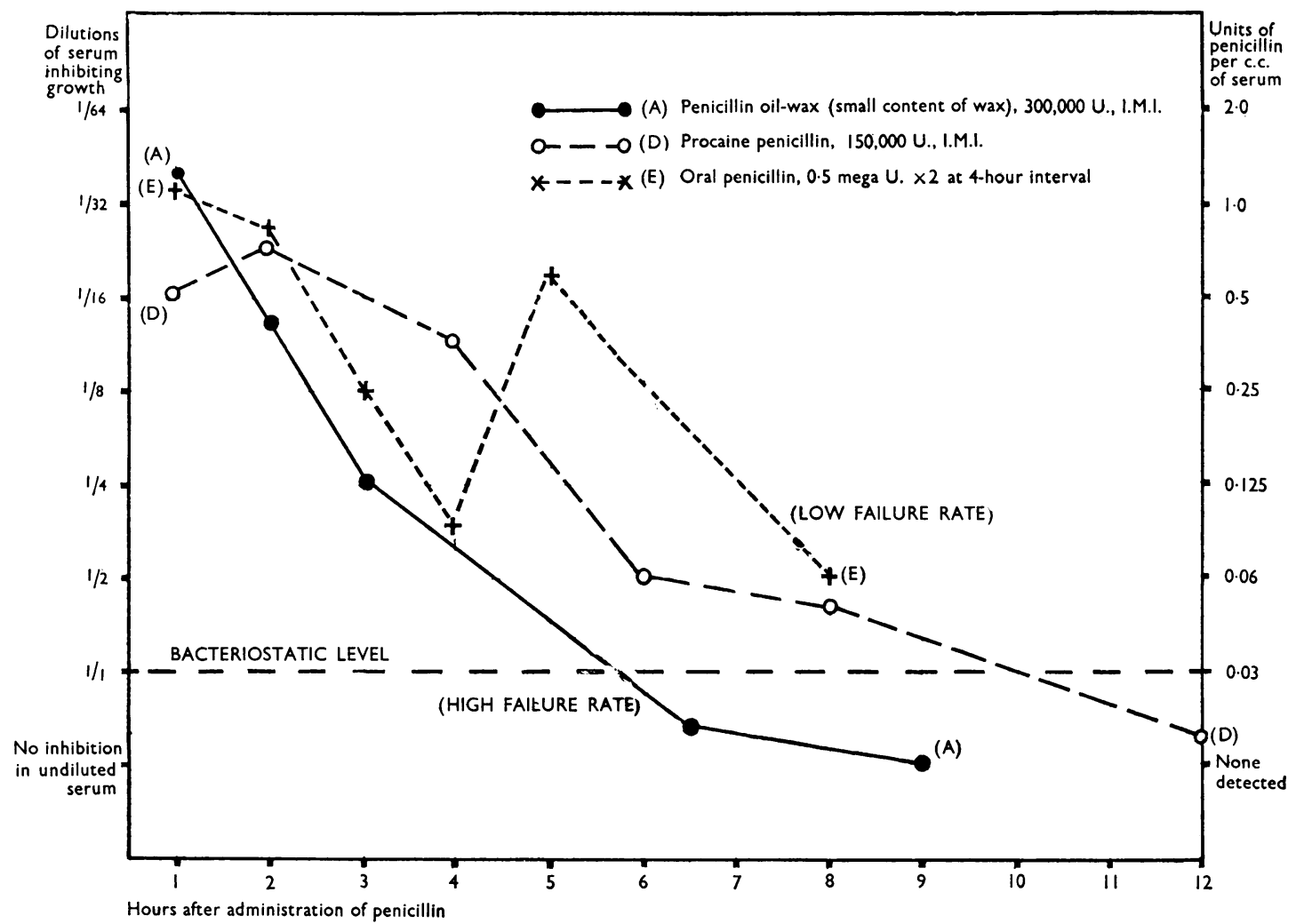

FIG.-Mean blood levels after oral and intramuscular administrations of penicillin. (Drawn from the data in Tables II and III, with the addition of sixteen observations on another eight cases at the 1st, 2nd, and 3rd hours after the first oral dose of penicillin.)

was strongly positive although there were no clinical signs of any stage of syphilis.

\section{Discussion}

Comparison of the failure rates in series $\mathrm{A}$ and $D$ with the blood penicillin levels suggests that the successful treatment of gonorrhœa depended on the maintenance of a bacteriostatic level $(0.03$ units penicillin per cc. of serum) for at least eight to ten hours (see Figure). This is at variance with the experience of Jones, Maitland, and Allen (1945), who found a high relapse rate when using parenteral penicillin in gonorrhœa when the bacteriostatic titre was not maintained for over eight hours at a serumdilution of $1: 8$, but a low relapse rate when it was maintained for over nine hours.

Oral penicillin, administered as tablets of the calcium salt buffered with sodium citrate, in two doses, each of 0.5 mega unit, at intervals of three to six hours, appeared to be as successful in the treatment of uncomplicated acute gonococcal urethritis in the male as any other form of treatment with penicillin. The fact that one of the cases failed to respond in spite of having a bacteriostatic level of penicillin in the blood for at least nine hours is of limited significance, as failures occasionally occur even after the administration of 300,000 units of procaine penicillin, when a bacteriostatic level can be expected for at least 24 hours. However, this case, the only failure in all those in which estimations of the blood penicillin level were made, showed a bacteriostatic level at the fourth and ninth hours. The value at the fourth hour was the lowest recorded at that time, and this can be taken as evidence that the blood level of penicillin is important therapeutically.

A possible criticism is that the large dose of penicillin (one mega unit by mouth) involves an increased risk of " masking" incubating syphilis, but, judging by blood levels, it is unlikely to be more dangerous in this respect than the standard dose of penicillin by injection.

In prescribing penicillin to be taken by mouth several important factors have to be considered. 
It is unlikely, from what is known of the blood levels after oral administration of penicillin, that a single dose of any of the available preparations would be sufficient to cure gonorrhœa. Except under continuous supervision, the taking of tablets every few hours for more than two or three doses is difficult to achieve even in the most conscientious patient as it necessarily encroaches on sleeping time. Patients with gonorrhœa are frequently unreliable and, as many of them have their treatment started at an evening clinic, even a third dose at this timespacing will probably necessitate interruption of sleep. As the majority will be free from symptoms after one to two doses there may not be even the local discomfort or the presence of a urethral discharge to prompt them to continue the tablets. It may be safe to assume, however, that a patient will take one dose in addition to the first one given under supervision when treatment is started. Therefore, a scheme of dosage that involved only two administrations of the tablets was used in this trial.

Previous reports on the successful treatment of gonorrhœa with oral penicillin described régimes involving six doses at three-hour intervals (Bushby and Harkness, 1946) and eight doses at one-hour intervals (Cohn, Kornblith, and Grunstein, 1946). Although the results showed that oral penicillin could be an adequate treatment for gonorrhœa, the frequency and duration of administration of the drug make the application of these régimes difficult for the reasons discussed above. The conclusion that twelve hours was too short a total duration, and four hours too long an interval between doses, using penicillin buffered with sodium citrate (Bushby and Harkness, 1946), is not confirmed by the results reported here, but they are not strictly comparable, as in the former series the individual doses were only 40,000 units. The relatively unsuccessful experience in a small series of cases reported by Seager and others (1946) suggests that penicillin contained in hard capsules is to be avoided.

A discussion of the circumstances under which gonorrhœa should be treated with oral penicillin rather than by injection is obviously controversial and will not be undertaken in this paper, but if oral treatment is to be employed it is essential to know what is the most effective régime. The relative expense of the two methods of treatment is difficult to assess, and is probably irrelevant. The dangers of the indiscriminate use of the oral method of treatment cannot be too strongly stressed.

\section{Summary}

1. Evidence is given which suggests that a high rate of cure in uncomplicated acute gonoccocal urethritis in the male is not obtained unless the blood penicillin level is at least 0.03 units per cc. of serum for at least eight hours. Six hours is not enough, and twelve hours may be unnecessarily long.

2. Blood penicillin levels after oral dosage of 0.5 mega unit are given.

3. An effective treatment of uncomplicated acute gonococcal urethritis in the male, using oral penicillin tablets, is described as a result of experience with fifty cases. Its application in the treatment of such cases is discussed. The potential dangers of the indiscriminate use of such a method are stressed.

The penicillin tablets were supplied by Glaxo Laboratories, Ltd. The author is indebted to Dr. W. M. Wilson, F.R.C.P.E., for carrying out the blood penicillin estimations, and to the medical and nursing staffs of the Department of Venereal Diseases, Royal Infirmary, Edinburgh, for their assistance in the care of the patients.

\section{REFERENCES}

Bushby, S. R. M., and Harkness, A. H. (1946). Lancet, 1, 783.

Cohn, A., Kornblith, B. A., and Grunstein, I. (1946). Amer. J. Syph., 30, 485.

Jones, T. R. L., Maitland, F. G., and Allen, S. J. (1945). Lancet, 1, 368.

Mackie, T. J., and McCartney, J. E. (1948). " Handbook of Practical Bacteriology." Edinburgh. 8th edition.

Seager, L. D., Shoemaker, W. G., Mulholland, S., Miller, R. E., Wells, G. R., and Barnes, K. B. (1946). J. Urol., 56, 594. 